\title{
DO LAGOMORPHS PLAY A RELAY ROLE IN THE EVOLUTION OF THE TRICHOSTRONGYLINA NEMATODES?
}

\author{
AUDEBERT F.*** \& DURETTE-DESSET M.C.*
}

Summary:

In order to confirm or refute the relay role of lagomorphs in the evolution of the Trichostrongylina (Nematoda), the following points were studied by summarizing previous works on the subject: the chronology of the life cycles $(27$ conducted in natural hosts, lagomorphs, ruminants or arvicolin rodents; 14 in experimental hosts); the parasitic phase in the experimental host and the adaptation involved; the migration of the parasites into the tissues of the host; the morphogenesis of larval stages and molecular phylogeny. These data confirm, in their entirety, that lagomorphs may be considered as "relay" hosts in the evolution of the Trichostrongylina.

KEY WORDS : Nematoda, Trichostrongylina, relay role, lagomorphs, ruminants, arvicolin rodents.

\section{INTRODUCTION}

A mong parasitic nematodes infesting terrestrial vertebrates, the Trichostrongylina are one of the largest groups, widespread throughout the world. The classification of this group, which is mainly based on morphological characters and their evolution, was proposed by Durette-Desset \& Chabaud (1977, 1981) and improved by Durette-Desset (1985) with the addition of some biological and ecological data. The correlation between the morphological characteristics of these parasites and the paleobiogeographic data of their hosts enabled these authors to propose a phyletic tree for this group. The sub-order Trichostrongylina was divided into three super-families by Durette-Desset \& Chabaud (1993): Trichostrongyloidea, Molineoidea and Heligmosomoidea. Remarkably, members of the three super-families are parasites of lagomorphs. From a phyletic point of view, lagomorphs played an evolutionary relay role between morphologically unchanged

\footnotetext{
* Département Systématique et Évolution, Muséum national d'Histoire naturelle, UMR 7138 associée au CNRS, BP 52, 61, rue Buffon, 75231 Paris Cedex 05, France.

** Laboratoire Informatique et Systématique, Université Pierre et Marie Curie, Paris 6, UMR 5143 associée au CNRS, 12, rue Cuvier, 75005 Paris, France.

Correspondence : Marie-Claude Durette-Desset.

E-mail : mcdd@mnhn.fr
}

Résumé : LES LAGOMORPHES ONT-ILS JOUÉ UN RÔLE DANS L'ÉVOlution des NÉmatodes TRichostrongylina?

Pour confirmer ou infirmer le rôle relais des Lagomophes dans l'évolution des Trichostrongylina (Nematoda), les points suivants ont été étudiés en synthétisant les travaux précédents sur le sujet la chronologie des cycles biologiques 127 cycles ont été réalisés chez l'hôte naturel, Lagomorphes, Ruminants ou Rongeurs Arvicolinae; 14 chez l'hôte expérimentall); la phase parasite chez l'hôte expérimental et l'adaptation qui en découle; la migration des parasites dans les tissus de l'hôte; la morphogenèse et la phylogénie moléculaire. Toutes ces données confirment que les Lagomorphes peuvent être considérés comme des hôtes "relais" dans l'évolution des Trichostrongylina.

MOTS CLÉS : Nematoda, Trichostrongylina, rôle relais, Lagomorphes, Ruminants, Rongeurs Arvicolinae.

hosts such as ratite birds or mammals that appeared in the early Eocene period, and more recent hosts, such as ruminants or arvicolin rodents (Durette-Desset \& Chabaud, 1977, 1981; Mc Kenna \& Bell, 1997).

The transfer amongst hosts lacking phyletic relationships is a general phenomenon in the nematode parasites of vertebrates and was defined by Chabaud (1965) as host-switching: a parasitic line may become isolated from its ancestral forms by passing from one host group to another; the isolation may be followed by evolutionary radiations of variable importance. In each super-family of the Trichostrongylina, host-switching may occur either at the time of the appearance and rapid diversification of a parasitic line which provides new ecological niches (for example the radiation of the Eutherian mammals at the beginning of the Tertiary) or between hosts having similar diets, such as the lagomorphs, ruminants and arvicolin rodents which are all herbivorous.

This classification is supported by biological data concerning these parasites. In strict herbivores, a derived life cycle appears with persistence of the sheathed infective larva, penetration of the host by the oral route only, and reduction of tissue migration. This recent life cycle contrasts with the life cycles of the majority of the Trichostrongylina, parasites of hosts which appeared during the Eocene period or which are not strict herbivores. These life cycles are charac- 


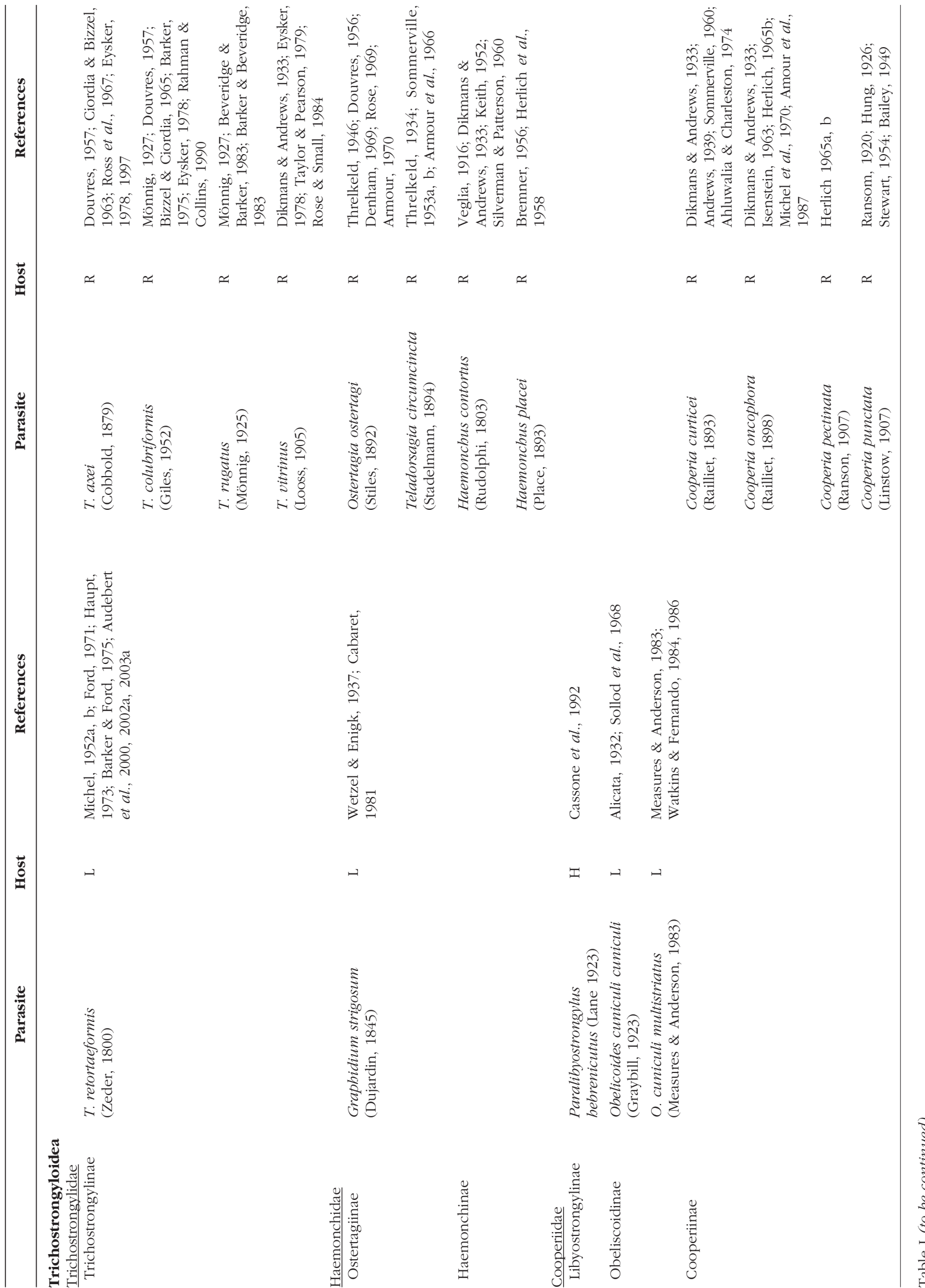




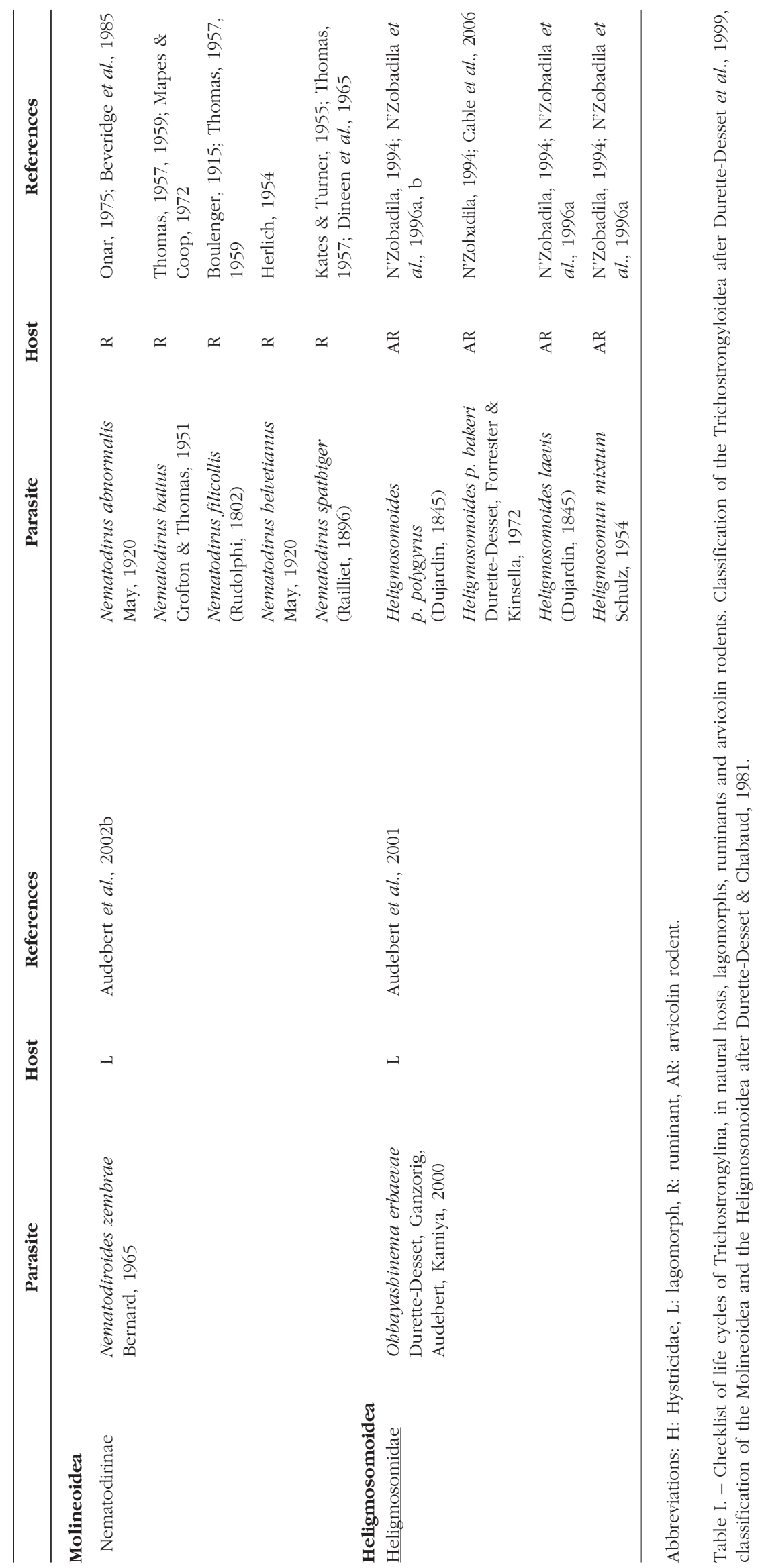


terized by an exsheathed infective larva, penetration by the cutaneous route, and pulmonary migration.

The aim of this work was to confirm or refute the relay role of lagomorphs in the evolution of the Trichostrongylina by summarizing previous works on the subject. Currently, 27 life cycles have been elucidated in natural hosts (lagomorphs, ruminant or arvicolin rodent), 16 in the Trichostrongyloidea, six in the Molineoidea and five in the Heligmosomoidea (Table I). 14 life cycles have been attempted in experimental hosts, eight in the Trichostrongyloidea, two in the Molineoidea, and four in the Heligmosomoidea (Table II).

Also, a phylogenetic analysis was conducted, based on DNA sequence data to provide a suitable alternative to analyses based on morphological data and to examine the phylogenetic relationships of the three super-families within the Trichostrongylina (Audebert et al., 2005). The most important points treated in this study concern the chronology of the life cycles in the natural hosts, the parasitic phase in an experimental host and the adaptation involved, the migration of the parasite into the tissues of the host, the morphogenesis of the larval stages and molecular phylogeny.

\section{MATERIALS AND METHODS}

$\mathrm{H}$ osts: in the Trichostrongyloidea and the Molineoidea, the experimental host is the rabbit (Oryctolagus cuniculus, Lilljeborg, 1874) (Lepo- ridae) for the switch ruminant/lagomorph. The switch lagomorph/ruminant has never been attempted. In the Heligmosomoidea, the experimental host is the common vole (Microtus arvalis, Pallas, 1779) (Arvicolinae) for the switch lagomorph/ arvicolin rodent and the pica (Ochotona rufescens rufescens, Gray, 1842) (Ochotonidae) for the switch arvicolin rodent/lagomorph.

Parasites: the life cycles have been completed or attempted in the following families or sub-families: Trichostrongylinae, Haemonchinae, Cooperiinae (Trichostrongyloidea), Nematodirinae (Molineoidea) and Heligmosomidae (Heligmosomoidea) (see Table I).

Definitions: the prepatent period is divided into two periods: the "larval period" from the infestation of the host up to the appearance of the immature worm (moult 4) and the "maturation period" from the appearance of the immature worm to the presence of eggs in the faeces of the host (Audebert et al., 2002a).

The fourth larval stage still sheathed in the cuticle of the third larval stage (or early L4) is designated as "(L4)" and the fourth larval stage exsheathed (or late L4) as "L4". DAI: day after the infestation.

Nomenclature and classification: the nomenclature used above the family group follows Durette-Desset \& Chabaud (1993). The classification used for the Trichostrongyloidea follows Durette-Desset et al., 1999 and that for the Molineoidea and the Heligmosomoidea Durette-Desset \& Chabaud, 1981.

\begin{tabular}{|c|c|c|c|}
\hline Parasite & Natural host & $\begin{array}{l}\text { Experimental } \\
\text { host }\end{array}$ & References \\
\hline \multicolumn{4}{|l|}{ Trichostrongyloidea } \\
\hline Trichostrongylus colubriformis & Cattle and other & Rabbit & $\begin{array}{l}\text { Ciordia et al., 1966; Purvis \& Sewell, } \\
\text { 1971, 1972; Audebert et al., 2003b }\end{array}$ \\
\hline Trichostrongylus vitrinus & Cattle, sheep and goat & Rabbit & Audebert et al., 2003b \\
\hline Trichostrongylus axei & Cattle, sheep and deer & Rabbit & $\begin{array}{l}\text { Drudge et al., 1955; Leland \& Drudge, } \\
\text { 1957; Ciordia et al., 1966; Haupt \& } \\
\text { Nickel, } 1975\end{array}$ \\
\hline Cooperia curticei & Sheep, goat, deer and mouflon & Rabbit & Wood \& Hansen, 1960 \\
\hline Cooperia punctata & Cattle and various wild ruminants & Rabbit & Besh, 1964, 1965; Alicata, 1958 \\
\hline Haemonchus contortus & Sheep, goat, cattle, bison and deer & Rabbit & $\begin{array}{l}\text { Wood \& Hansen, 1960; Hutchinson } \\
\text { \& Slocombe, 1976; Mapes \& Gallie, } \\
1977\end{array}$ \\
\hline Ostertagia ostertagi & Cattle & Rabbit & $\begin{array}{l}\text { Snider et al., 1985, Boisvenue \& } \\
\text { Novilla, } 1992\end{array}$ \\
\hline Teladorsagia circumcincta & $\begin{array}{l}\text { Sheep, deer, llamas, mouflon, bighorn } \\
\text { sheep and antelope }\end{array}$ & Rabbit & Zebrowska-Plata, 1980 \\
\hline \multicolumn{4}{|l|}{ Molineoidea } \\
\hline Nematodirus battus & Sheep, goat and cattle & Rabbit & Gallie, 1972 \\
\hline Nematodirus spathiger & Sheep, goat and cattle & Rabbit & Audebert et al., 2004 \\
\hline \multicolumn{4}{|l|}{ Heligmosomoidea } \\
\hline Obbayashinema erbaevae & Ochoton & Field mouse & Audebert, 1999 \\
\hline Heligmosomoides polygyrus polygyrus & Field mice & Mouse & N'Zobadila, 1994 \\
\hline Heligmosomoides polygyrus bakeri & Mouse & Field mouse & N’Zobadila, 1994 \\
\hline Heligmosomoides laevis & Field mice & Ochoton & Audebert, 1999 \\
\hline
\end{tabular}

Table II. - Checklist of studies concerning parasitic stages of parasites of lagomorphs, ruminants or arvicolin rodents in experimental hosts. Classification of the Trichostrongyloidea after Durette-Desset et al., 1999, classification of the Molineoidea and the Heligmosomoidea after Durette-Desset \& Chabaud, 1981. 


\section{SYNTHESIS OF THE DATA}

\section{Chronology OF THE LIFE CYCLES IN NATURAL HOSTS}

- Free phase

The duration of the free phase is from three to nine days in the Trichostrongyloidea, from eight to 30 days in the Molineoidea and from three to six days in the Heligmosomoidea (Table III).

- Parasitic phase

The duration of the larval period is from four to 15 days in the Trichostrongyloidea, from 10 to 15 in the Molineoidea and from four to seven in the Heligmosomoidea. The duration of the maturation period is from two to 16 in the Trichostrongyloidea, from two to 10 in the Molineoidea and from four to eight in the Heligmosomoidea. The duration of the prepatent period varies from 11 to 30 days in the Trichostrongyloidea, from 14 to 21 days in the Molineoidea and from eight to 14 days in the Heligmosomoidea (Table III).

PARASITIC PHASE IN THE NATURAL HOST; COMPARISON BETWEEN THE LIFE CYCLES IN LAGOMORPHS AND THOSE IN RUMINANTS/ARVICOLIN RODENTS

In the Trichostrongyloidea, the larval period is shorter in lagomorphs than in ruminants or equivalent. The maturation period is shorter in lagomorphs. The prepatent period is shorter or equivalent in lagomorphs (Fig. 1A, B).

In the Molineoidea, the larval period is shorter in lagomorphs than in ruminants or equivalent and the maturation period is equivalent. The prepatent period is equivalent or longer in lagomorphs than in ruminants (Fig. 1C).

In the Heligmosomoidea the larval period and the maturation period are shorter in lagomorphs than in

\begin{tabular}{|c|c|c|c|c|c|c|c|c|}
\hline \multirow[b]{2}{*}{ Species } & \multirow[b]{2}{*}{ Host } & \multirow[b]{2}{*}{ Location } & \multirow{2}{*}{$\begin{array}{c}\text { Morphogenesis } \\
\text { NIC } \\
\text { of (L3) }\end{array}$} & \multirow{2}{*}{$\begin{array}{c}\text { Free living stage } \\
\text { Appearance } \\
\text { of (L3) } \\
\text { DAC }\end{array}$} & \multicolumn{2}{|c|}{ Parasitic stage } & \multirow[b]{2}{*}{$\begin{array}{c}\text { Arrested } \\
\text { development }\end{array}$} & \multirow[b]{2}{*}{$\begin{array}{c}\text { Prepatent } \\
\text { period }\end{array}$} \\
\hline & & & & & $\begin{array}{c}\text { Moult } 3 \\
\text { DAI }\end{array}$ & $\begin{array}{c}\text { Moult } 4 \\
\text { DAI }\end{array}$ & & \\
\hline Trichostrongyloidea & & & & Free larva & & & & \\
\hline Tr. retortaeformis & $\mathrm{L}$ & intestine & 16 & 5 & $3 \& 5$ & $4 \& 6$ & (L4) & $12 \& 13$ \\
\hline Tr. colubriformis & $\mathrm{R}$ & intestine & 16 & 4 & 3 to 4 & $6 \& 10$ & (L4) & $18 \& 21$ \\
\hline Tr. vitrinus & $\mathrm{R}$ & intestine & 16 & 3 to 5 & 4 & 11 & L3 & 19 \\
\hline Tr. axei & $\mathrm{R}$ & intestine & 16 & 4 & 4 to 6 & 10 & L3 & 19 \\
\hline Tr. rugatus & $\mathrm{R}$ & intestine & 16 & 3 & 4 to 6 & 10 & absent & 16 to 18 \\
\hline G. strigosum & $\mathrm{L}$ & stomach & 16 & 3 to 5 & 2 to 9 & 11 & L4 & 13 \\
\hline Te. circumcincta & $\mathrm{R}$ & stomach & 16 & 4 to 6 & 3 to 4 & 8 & $\mathrm{~L} 4$ & 18 \\
\hline H. contortus & $\mathrm{R}$ & stomach & 16 & 3 & 3 & 9 to 11 & (L4) & 11 \\
\hline H. placei & $\mathrm{R}$ & stomach & ud & ud & 2 & 11 to 15 & $\mathrm{~L} 4$ & $24 \& 30$ \\
\hline Os. ostertagi & $\mathrm{R}$ & stomach & 16 & 5 to 6 & 3 & 7 to 10 & $\mathrm{~L} 4$ & 23 \\
\hline O. cuniculi cuniculi & $\mathrm{L}$ & stomach & 16 & 6 & 3 to 5 & 6 to 14 & (L4) & 16 to 20 \\
\hline O. cuniculi multistriatus & $\mathrm{L}$ & stomach & ud & 7 to 8 & 3 & 8 to 11 & (L4), L4 & 16 to 22 \\
\hline C. curticei & $\mathrm{R}$ & intestine & 16 & 9 & 4 & 8 to 10 & L4 & 15 \\
\hline C. oncophora & $\mathrm{R}$ & intestine & 16 & 5 & 4 & 10 & (L4) & 17 to 22 \\
\hline C. pectinata & $\mathrm{R}$ & intestine & 16 & ud & 3 & 8 to 10 & L4 & 14 to 17 \\
\hline C. punctata & $\mathrm{R}$ & intestine & 16 & 3 to 4 & 3 & 7 to 8 & ud & 12 to 16 \\
\hline Molineoidea & & & & In shell & & & & \\
\hline Nes. zembrae & $\mathrm{L}$ & intestine & 8 & 10 to 15 & 6 & 11 & absent & 21 \\
\hline Nus. abnormalis & $\mathrm{R}$ & intestine & 8 & 16 & 4 & 12 to 14 & (L4) & 19 \\
\hline Nus. battus & $\mathrm{R}$ & intestine & 8 & 28 to 30 & 4 & 10 to 12 & L4 and Im & 14 \\
\hline Nus. filicollis & $\mathrm{R}$ & intestine & 8 & 24 to 27 & 5 & 12 & L4 and Im & 14 to 21 \\
\hline Nus, helvetianus & $\mathrm{R}$ & intestine & 8 & 8 to 20 & 8 & 15 & L4 & 21 \\
\hline Nus. spathiger & $\mathrm{R}$ & intestine & 8 & 14 & 5 & 11 & L4 & 14 \\
\hline Heligmosomoidea & & & & Free larva & & & & \\
\hline Oh. erbaevae & $\mathrm{L}$ & intestine & 20 & 4 to 5 & 2.5 & 4 & absent & 8 \\
\hline Hes. laevis & $\mathrm{AR}$ & intestine & 20 & 4 & 2.5 & 5 & absent & 9 to 12 \\
\hline Hes. polygyrus polygyrus & $\mathrm{AR}$ & intestine & 20 & 6 & 3 to 4 & 5 to 7 & absent & 11 \\
\hline Hes. polygyrus bakeri & $\mathrm{AR}$ & intestine & 20 & 6 & 4 & 6 & absent & 11 \\
\hline Hum mixtum & $\mathrm{AR}$ & intestine & 20 & 3 & 2.5 & 6 & absent & 13 to 14 \\
\hline
\end{tabular}

Abbreviations: Tr: Trichostrongylus, G: Graphidium, Te: Teladorsagia, H: Haemonchus, Os: Ostertagia, O: Obeliscoides, C.: Cooperia, Nes: Nematodiroides, Nus: Nematodirus, Ob: Ohbayashinema, Hes: Heligmosomoides, Hum: Heligmosomum. ud: unavailable data, NIC: number of intestinal cells, L: lagomorphs, R: ruminants, AR: arvicolin rodents, DAI: day after infestation, DAC: day after coproculture, L3: larva of stage 3, (L4): larva of stage 4 sheathed in L3 cuticle, L4: larva of stage 4, Im: immature worm; $\mathrm{n}^{\circ}$ to $\mathrm{n}$ : same author, two data, $\mathrm{n}^{\circ} \& \mathrm{n}^{\circ}$ : different authors. In order to simplify the synthesis of data, the first date in the chronology for each species has been retained.

Table III. - Synthesis of data of life cycles of Trichostrongylina in natural hosts, lagomorphs, ruminants and arvicolin rodents. 


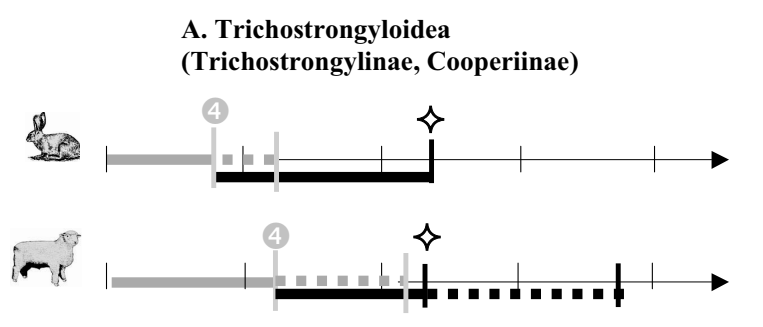

B. Trichostrongyloidea

(Obeliscoidinae, Ostertagiinae, Haemonchinae)

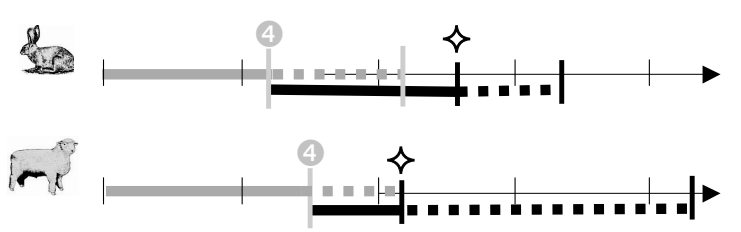

C. Molineoidea (Nematodirinae)

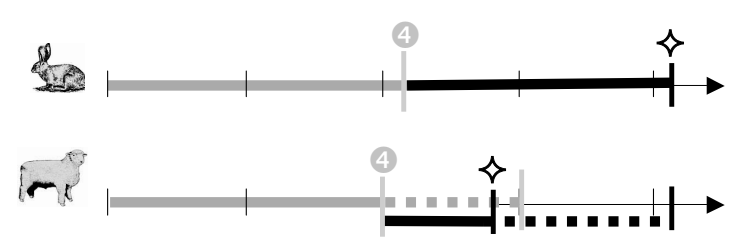

D. Heligmosomoidea (Heligmosomidae)

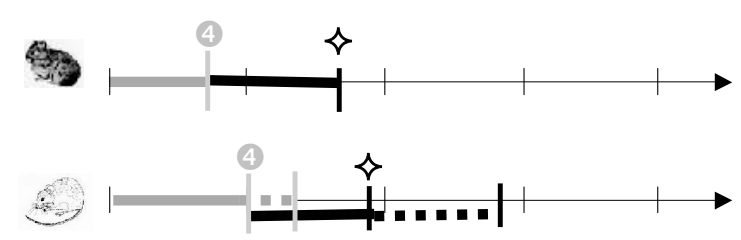

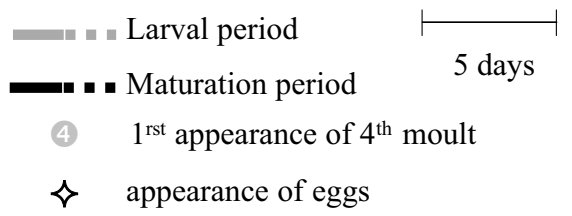

Fig. 1. - Chronology of parasitic life cycle in natural host; comparison between lagomorphs/ruminants and lagomorphs/arvicolin rodents. A: Trichostrongylus retortaeformis in rabbit and T. axei, T. colubriformis, T. vitrinus, Cooperia curticei, C. oncophora, C. pectinata, C. punctata in ruminants. B: Obeliscoides cuniculi cuniculi, O. c. multistriatus, Graphidium strigosum in rabbits and Teladorsagia circumcincta, Haemonchus contortus, H. placei, Ostertagia ostertagi in ruminants. C: Nematodiroides zembrae in rabbit and Nematodirus abnormalis, N. battus, N. filicollis, N. helvetianus, N. spatbiger in ruminants. D: Obbayashinema erbaevae in ochoton and Heligmosomoides laevis, H. polygyrus polygyrus, H. p. bakeri, Heligmosomum mixtum in arvicolin rodents.

The prepatent period is divided into "the larval period", illustrated in light print and "the maturation period" in dark print. In the case of several species, the continuous line corresponds to the species with the shortest larval period and the shortest maturation period. The dotted line corresponds to the other species. In order to simplify the synthesis of data the first date in the chronology for each species has been retained. Scale: 5 days.

arvicolin rodents. The prepatent period is shorter in lagomorphs (Fig. 1D).

\section{PARASITIC PHASE IN AN EXPERIMENTAL HOST; COMPARISON BETWEEN THE LIFE CYCLE IN THE NATURAL HOST AND IN THE EXPERIMENTAL HOST (Table IV)}

- Passage in experimental host

In the Trichostrongyloidea living in the small intestine (Trichostrongylinae, Cooperiinae) and in the Molineoidea (Nematodirinae), the life cycle can be completed and eggs are found in the faeces of the host (Fig. 2A, C).

In the Trichostrongyloidea living in the stomach (Ostertagiinae, Haemonchinae), the life cycle either stops at the L4 stage or else continues until the maturation of the adults but there is no presence of eggs in the faeces (Fig. 2B). In Haemonchus contortus, infestation by artificially exsheathed larvae results in recovery of only immature worms.

In the Heligmosomoidea (Heligmosomidae), there is no longer a host switch either from the ochoton to the arvicolin rodent or from the arvicolin rodent to the ochoton (Fig. 2D).

- Duration of the prepatent period

In the Trichostrongyloidea, the prepatent period is shorter in the natural host. The larval period is shorter and the maturation period is shorter or equivalent (Fig. 2A, B).

In the Molineoidea, the prepatent period, the larval period and the maturation period are equivalent (Fig. 2C). In the Heligmosomoidea the comparison is not possible (Fig. 2D) because up to now it has been impossible to carry out a life cycle, the host switches arvicolin rodent/lagomorph and lagomorph/arvicolin rodent having been unsuccessful.

- Success rate of the infestation in experimental hosts In the Trichostrongyloidea, the success rate of the switch ruminant/lagomorph is between $2.7 \%$ and $23 \%$ for the Trichostrongylinae (Table IV). In the Ostertagiinae, Cooperiinae and the Haemonchinae, the success rate is significantly lower between $0.01 \%$ and $11 \%$. 


\begin{tabular}{|c|c|c|c|c|c|c|}
\hline \multirow[b]{2}{*}{ Species } & \multirow[b]{2}{*}{$\begin{array}{l}\text { Experimental } \\
\text { host }\end{array}$} & \multirow[b]{2}{*}{$\begin{array}{l}\text { Success } \\
\text { rate }(\%)\end{array}$} & \multicolumn{3}{|c|}{ Parasitic stage } & \multirow[b]{2}{*}{ Comments } \\
\hline & & & $\begin{array}{c}\text { Moult } 3 \\
\text { DAI }\end{array}$ & $\begin{array}{c}\text { Moult } 4 \\
\text { DAI }\end{array}$ & $\begin{array}{l}\text { Prepatent } \\
\text { period }\end{array}$ & \\
\hline \multicolumn{7}{|l|}{ Trichostrongyloidea } \\
\hline Tr. colubriformis & rabbit & 4.2 to 23 & 4 & 10 & 16 & Eggs in faeces \\
\hline Tr. vitrinus & rabbit & 2.7 to 10.5 & 8 & 12 & 20 & Eggs in faeces \\
\hline Tr. axei & rabbit & 18.6 & 8 & 14 & 22 & Eggs in faeces \\
\hline C. curticei & rabbit & 2.5 to 6.25 & ud & ud & 18 & $\begin{array}{l}\text { A small proportion capable of } \\
\text { development }\end{array}$ \\
\hline C. punctata & rabbit & 0.01 to 9.20 & ud & ud & $11-16$ & Mature worms are shorter than in calves \\
\hline H. contortus & rabbit & 0.3 to 11 & $5-7$ & $9-12$ & No eggs & $\begin{array}{l}\text { Artificially exsheathed, early L4, few } \\
\text { immature worms }\end{array}$ \\
\hline Os. ostertagi & rabbit & 3.34 & before 12 & before 28 & No eggs & Early L4 and immature worms \\
\hline Te. circumcincta & rabbit & 0.47 to 0.56 & ud & 10 & No eggs & $\begin{array}{l}\text { Many L4 and few immature with } 4^{\text {th }} \\
\text { sheath }\end{array}$ \\
\hline \multicolumn{7}{|l|}{ Molineoidea } \\
\hline Nus. battus & rabbit & 14.52 & 4 & 10 & 16 & Some larvae L4 inhibited in development \\
\hline Nus. spathiger & rabbit & 9.53 & 4 & 13 & 21 & Some larvae $\mathrm{L} 4$ inhibited in development \\
\hline \multicolumn{7}{|l|}{ Heligmosomoidea } \\
\hline Oh. erbaevae & Arvicolin rodent & 0 & - & - & - & No development \\
\hline Hes. polygyrus polygyrus & mouse & 2.7 & $4-7$ & 8 & No eggs & Pseudocyst, expulsion of worms at $9 \mathrm{DAI}$ \\
\hline Hes. polygyrus bakeri & Arvicolin rodent & 3.9 & before 8 & before 16 & More 16 & Asynchrony of moult \\
\hline Hes. laevis & Ochotona & 0 & - & - & - & No development \\
\hline
\end{tabular}

Abbreviations: Tr.: Trichostrongylus, C.: Cooperia, H: Haemonchus, Os: Ostertagia, Te: Teladorsagia, Nus: Nematodirus, Ob: Ohbayashinema, Hes: Heligmosomoides, DAI: day after infestation, L4: larva of stage 4, ud: unavailable data.

Table IV. - Synthesis of data concerning parasitic stages of Trichostrongylina in experimental hosts.
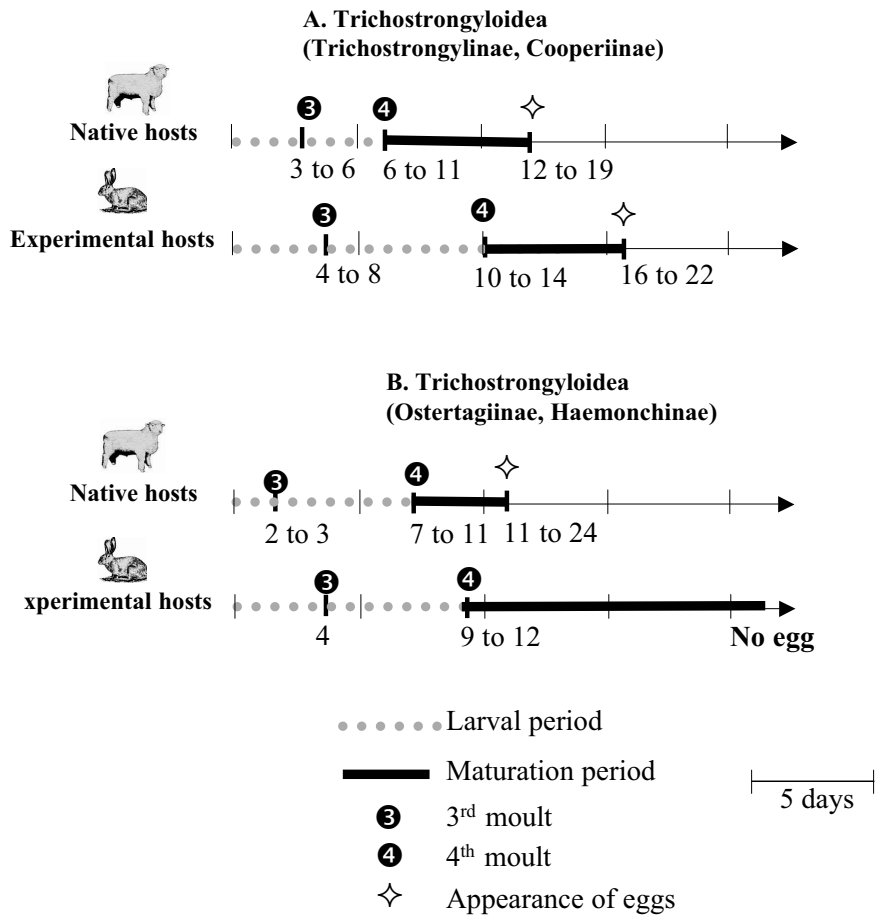

C. Molineoidea (Nematodirinae)

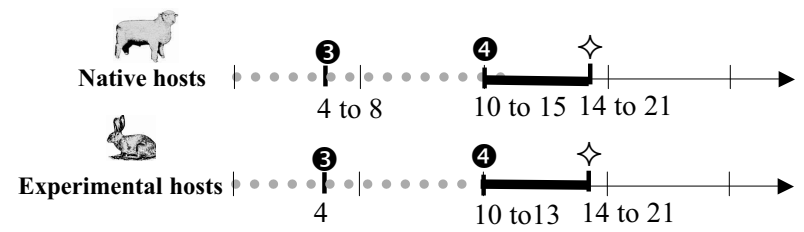

D. Heligmosomoidea (Heligmosomidae)

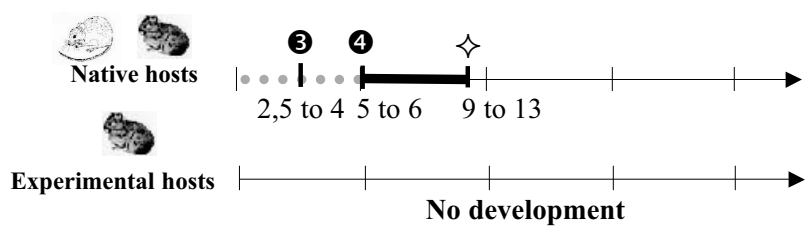

Fig. 2. - Chronology of parasitic life cycle; comparison between natural host and experimental host.

A: Trichostrongylus axei, T. colubriformis, T. vitrinus, Cooperia curticei, C. oncophora, C. pectinata, C. punctata in ruminants compared with Trichostrongylus axei, T. colubriformis, T. vitrinus, Cooperia curticei, C. punctata in experimental host, the rabbit. B: Teladorsagia circumcincta, Haemonchus contortus, H. placei, Ostertagia ostertagi in ruminants compared with Teladorsagia circumcincta, Haemonchus contortus, Ostertagia ostertagi in an experimental host, the rabbit. C: Nematodirus abnormalis, $N$. battus, N. filicollis, N. helvetianus, N. spathiger in ruminants compared with $N$. battus, $N$. spathiger in an experimental host, the rabbit. D: Heligmosomoides laevis, H. polygyrus polygyrus, H. p. bakeri, Heligmosomum mixtum in arvicolin rodents compared with Heligmosomoides laevis in an experimental host, the ochoton. Scale: 5 days. 
In the Molineoidea (Nematodirinae), the success rate of the switch ruminant/lagomorph is between $9.5 \%$ and $14.5 \%$.

In Heligmosomoidea, no success rate.

\section{LOCATION OF LARVAL STAGES}

IN THE DIGESTIVE MUCOSA AND ARRESTED DEVELOPMENT (Tables I, III)

The data provided by the authors are heterogeneous and therefore difficult to compare. Nevertheless it is possible to group them by host and by super-family.

- Location of parasites

a. In lagomorphs

In the Trichostrongyloidea, the L3 penetrate the intramucosal capillaries (Trichostrongylus retortaeformis) (Audebert et al., 2003a) or form ulcerations in the submucosa (Obeliscoides spp.) (Alicata, 1932). In the Molineioidea and the Heligmosomoidea, only the head is located in the mucosa (Nematodiroides, Obbayashinema) (Audebert et al., 2001, 2002b).

b. In ruminants

In the intestinal Trichostrongyloidea (Trichostrongylus spp. and Cooperia spp.), and in Molineoidea, the L3 superficially penetrates the epithelium (Bailey, 1949; Kates \& Turner, 1955; Herlich, 1965b; Barker, 1975; Taylor \& Pearson, 1979; Barker \& Beveridge, 1983; Armour et al., 1987). In the gastric Trichostrongyloidea, the penetration is more superficial (Haemonchus spp.) (Silverman \& Patterson, 1960) progressing to the formation of nodules in Teladorsagia circumcincta and Ostertagia ostertagi (Sommerville, 1953b; Armour, 1970)

c. In arvicolin rodent

In the Heligmosomoidea, the penetration is very deep resulting in the formation of pseudocysts located in the intestinal sub-mucosa, or musculosa or pedounculated in the abdominal cavity (N'Zobadila et al., 1996b).

The duration inside the mucosa varies. Depending on the species of the parasite either the L4 or immature worms or adults reach the gastric or intestinal lumen, their definitive location, where coupling occurs.

\section{- Arrested development}

Arrested development is present in the Trichostrongyloidea and Molineoidea both in lagomorphs and ruminants. This phenomenon was the subject of a very detailed study of Michel (1974) and of various authors after him (Anderson et al., 1965, Ogunsusi \& Eysker, 1979; Watkins \& Fernando, 1984, 1986; Gibbs, 1986; Eysker, 1978, 1997). The arrested development takes place at L3 or (L4) stage for Trichostrongylus spp., (L4) or L4 for the other genera. In the Molineoidea, it takes place at (L4) or L4 or immature stage.

In the Heligmosomoidea (Heligmosomidae), arrested development does not exist because pseudocysts empty themselves and disappear from the beginning of the patent period (N'Zobadila et al., 1996b).

\section{Morphogenesis (Fig. 3, Tables I, III)}

Study of the larval morphogenesis during the life cycle of the Trichostrongylina highlights three significant points.

- Intestinal cell number of the free living stages In each super-family, the number of intestinal cells of the free-living stage is constant. There are 16 in the Trichostrongyloidea (Veglia, 1916; Mönnig, 1927; Dikmans \& Andrews, 1933; Douvres, 1957), eight in the Molineoidea (Nematodirinae) (Thomas, 1957; Audebert et al., 2002b) and 20 in the Heligmosomoidea (Heligmosomidae) (N'Zobadila et al.; 1996a; Audebert et al., 2001) (Table III).

- Shape of the tails of the larvae

In the Trichostrongyloidea, the tail of the free-living stages has a sharp tip and that of the L4 is rounded

\section{Tails}

\section{Synlophes}

Trichostrongyloidea

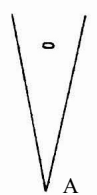

L1,L2, (L3), L3

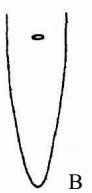

L4

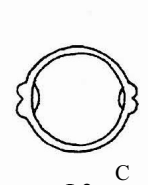

L3 Trichostrongylidae $\begin{aligned} & \text { Haemonchidae } \\ & \text { Cooperidae }\end{aligned}$

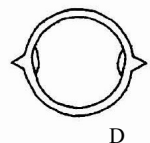

D $\mathrm{L} 4$

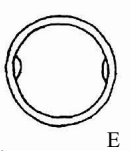

Molineoidea
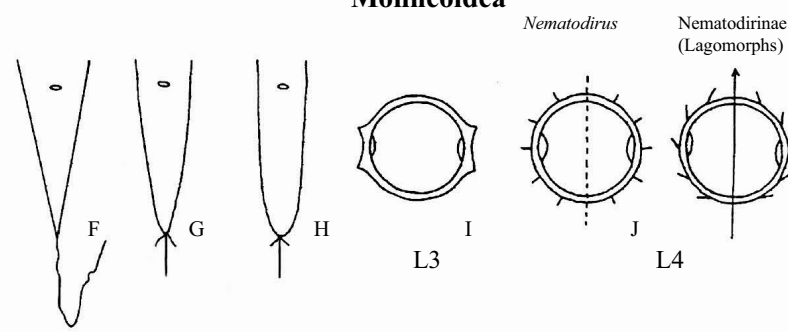

(Lagomorphs)

L1,L2, (L3)

L4

Heligmosomoidea
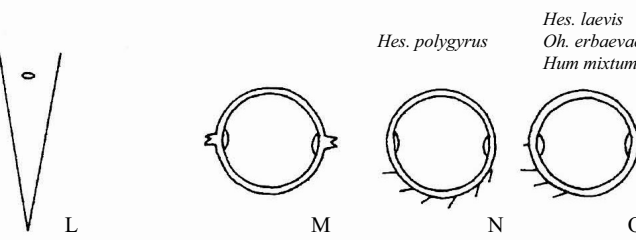

Hes. polygyrus Oh. erbaevae Hum mixtum
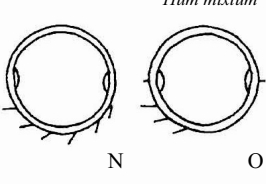

L1,L2, (L3), L3, L4

L3

L4

Fig. 3. - Morphological features of Trichostrongylina larvae during the ontogenesis; tails and synlophes.

A-E: Trichostrongyloidea, A-B: tails, C-E: transverse sections at midbody. F-K: Molineoidea, F-H: tails, I-K: transverse sections at midbody. L-O: Heligmosomoidea, L: tails, M-O: transverse sections at midbody.

Abbreviations: L1: larva of stage 1, L2: larva of stage 2, (L3): larva of stage 3 sheathed in L2 cuticle, L3: larva of stage 3, L4: larva of stage 4. . Ob: Ohbayashinema, Hes: Heligmosomoides, Hum: Heligmosomum. 
(Fig. 3A, B), (Mönnig, 1927; Douvres, 1957; Audebert et al., 2000). In the Molineoidea, the tails of L1, L2 and (L3) are whip-shaped (Fig. 3F). The tails of L3 and L4 are complex with several sharp tips, the longest being the median or the ventral (Fig. 3G, H) (Beveridge et al., 1985; Audebert et al., 2002b). In the Heligmosomoidea, the tails of L1 to L4 are simple and sharp (Fig. 3L) (N'Zobadila et al., 1996a; Audebert et al., 2001).

- Shape of the L3 lateral alae

In the Trichostrongyloidea, the L3 possesses small lateral alae, in the form of a double swelling (Fig. 3C) (Audebert et al., 2000). In the Molineoidea, the L3 has two lateral alae made up of two triangular ridges well separated from each other (Fig. 3I) (Beveridge et al., 1985; Audebert et al., 2002b). In the Heligmosomoidea, the L3 has two lateral bifid alae (Fig. 3M) (N'Zobadila et al., 1996a; Audebert et al., 2001).

- Synlophe of the L4

In the Trichostrongyloidea, the synlophe of the L4 is absent in the Haemonchidae and the Cooperidae (Fig. 3E) or reduced to two triangular-shaped lateral alae, in species of the genus Trichostrongylus, parasites of lagomorphs or ruminants (Fig. 3D) (Audebert et al., 2000). In the Molineoidea, the synlophe of both parasites of lagomorphs and ruminants presents a bilateral symmetry. In Nematodirus spp., a parasite of ruminants, the synlophe is made up of 10 cuticular ridges, orientated perpendicularly to the body surface (Fig. 3J) (Beveridge et al., 1985); In Rauschia and Nematodiroides, both parasites of lagomorphs, it has an axis of orientation directed from the ventral to dorsal side (Fig. 3K) (Audebert et al., 2002b). In the Heligmosomoidea, the synlophe never possesses a bilateral symmetry. In Heligmosomoides polygyrus, a parasite of rodents, it is made up of six small ventral ridges, orientated from right to left (Fig. $3 \mathrm{~N})\left(\mathrm{N}^{\prime} \mathrm{Zo}-\right.$ badila et al., 1996a). In the other Heligmosomidae studied, Obbayashinema erbaevae, a parasite of lagomorphs, and Heligmosomoides laevis and Heligmosomum mixtum, both parasites of rodents, there are three well developed ventral ridges and two tiny lateral ridges orientated perpendicularly to the body (Fig. 3O) (N'Zobadila et al., 1996a; Audebert et al., 2001).

\section{MOLECUlar PHYLOGENY}

Each super-family of Trichostrongylina represents a clade. Within the Trichostrongylina, the Trichostrongyloidea represents the sister group to a clade comprising the Heligmosomoidea and Molineoidea. These results were robustly sustained by high bootstrap and decay index values (see Audebert et al., 2005). Trichostrongylus retortaeformis and Graphidium strigosum, parasites of lagomorphs are in the clade of the Tricho-

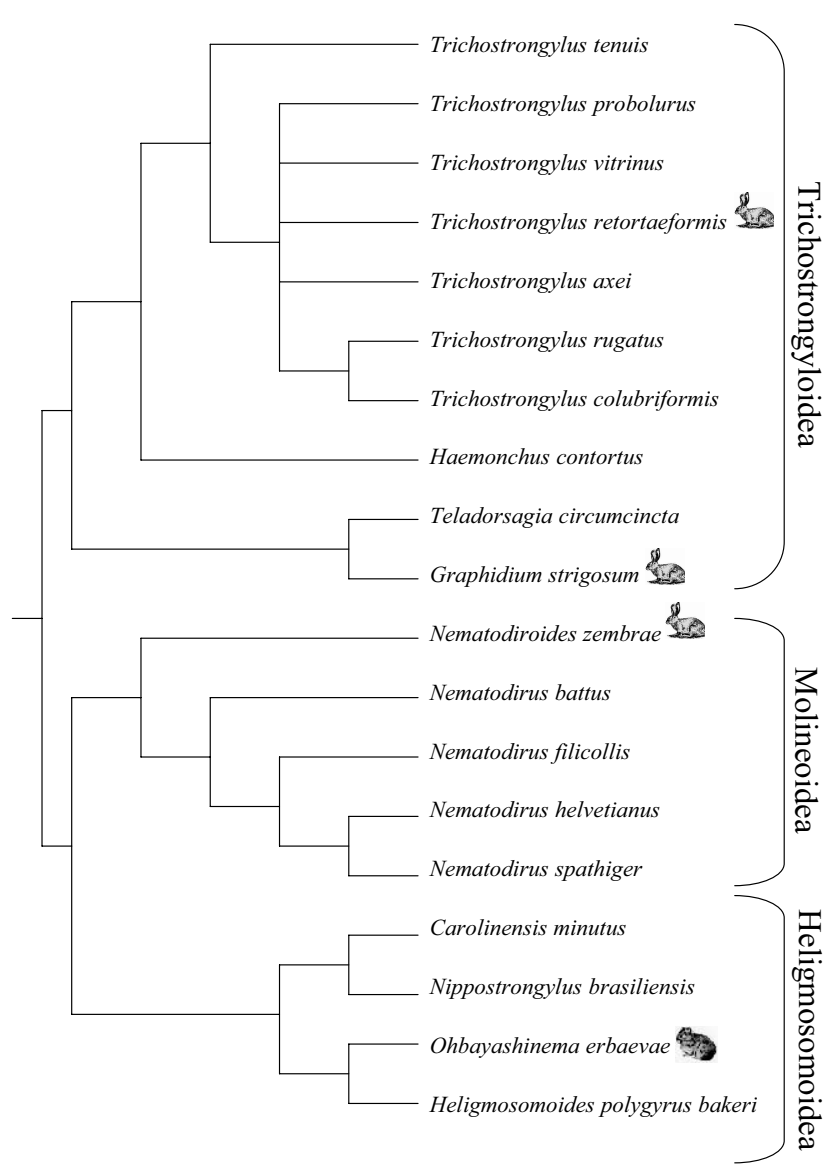

Fig. 4. - Cladogram depicting phylogenetic relationships of 19 species of nematodes within suborder Trichostrongylina, parasites of lagomorphs, ruminants and arvicolin rodents. The animal drawings next to the taxa show the parasites of lagomorphs.

After Audebert et al., 2005.

strongyloidea with the parasite of ruminants. Nematodiroides zembrae, a parasite of lagomorphs, is the sister group of Nematodirus spp., parasites of ruminants. Obbayashinema erbaevae, a parasite of ochotons, is in the clade of the Heligmosomidae parasites of the arvicolin rodents (Fig. 4).

\section{INTERPRETATION OF DATA}

\section{ChronOlOgy OF THE LIFE CYCLES IN NATURAL HOSTS}

- Free phase

The duration of the free phase is similar in the Trichostrongyloidea and the Heligmosomoidea (3 to 9 days) whereas the duration is about one to four weeks in the Molineoidea. This difference could be explained by the fact that development occurs inside the egg in the Molineoidea.

- Parasitic phase

The duration of the life cycle may be correlated with the ecology of the hosts. The "r" strategy or "savannah" 
type, is characterized by a fast reproductive cycle and a short life span, unlike the "k" strategy or "forest" type, characterized by a slow reproductive cycle and a long life span. The herbivorous hosts, which are studied in the present work, originate mainly from the savannah, which implies that their parasites also develop very quickly. Ochotons live in the mountains, not in the savannah. However the duration of the life cycle of their parasites is very short, like type " $\mathrm{r}$ " because ochotons experience a short warm season, which explains the rapid rhythm of reproduction of both host and parasite.

PARASITIC PHASE IN THE NATURAL HOST; COMPARISON BETWEEN THE LIFE CYCLES IN LAGOMORPHS AND THOSE IN RUMINANTS/ARVICOLIN RODENTS

The results are different for each of the three superfamilies: in the Trichostrongyloidea, the prepatent period is equivalent in lagomorph and ruminants; in the Molineoidea, the prepatent period is longer in lagomorphs than in ruminants, in the Heligmosomoidea, the prepatent period is shorter in lagomorphs than in arvicolin rodents.

\section{PARASITIC PHASE IN AN EXPERIMENTAL HOST; COMPARISON BETWEEN THE CYCLE IN} THE NATURAL HOST AND IN THE EXPERIMENTAL HOST: ADAPTATION TO THE EXPERIMENTAL HOST (Fig. 2)

In each case where the establishment of a parasite in an experimental host is still possible, the adaptation results in a lengthening of the larval period due mainly to the later appearance of moult 4, except for the Molineoidea where the duration of the larval period in the natural host and the experimental host do not change (Fig. 2).

One of the hypotheses put forward to explain the inability of the Haemonchidae to carry out their life cycle is that the acidity of the stomach of rabbits is insufficient to allow the development of the larvae. The rabbit is an abnormal host for ruminant parasites and since the digestive tract is very different from that of ruminants, it is conceivable that the normal growth pattern as well as the gross morphology of the worms may be influenced by various factors associated with this unusual habitat.

In the Heligmosomoidea, the life cycle in an experimental host is impossible and yet morphologically speaking, Ohbayashinema and Heligmosomoides are very closely linked. This is in keeping with the observations of N'Zobadila (1994) even those concerning the genus Heligmosomoides itself. This author carried out cross infestations between $H$. p. bakeri Durette-Desset et al., 1992, a parasite of the domestic mouse in the USA and H.p.polygyrus (Dujardin, 1845) a parasite of Apodemus sylvaticus in Europe. In experimental condi- tions, the life cycle of $H$. p. polygyrus in the mouse cannot proceed beyond the appearance of the juvenile worms and the adult worms are expelled 9 DAI. The life cycle of H. p. bakeri in Apodemus, by contrast, develops a longer maturation period. At 16 DAI, the end of the experiment, the worms are still at the immature stage. Moreover, the rate of establishment for both species is very low, 3 and $4 \%$, respectively. In this group, the biological features concerning parasitic specificity thus appear more marked than the morphological features. This biological observation was recently confirmed by molecular data in Cable et al., 2006.

\section{LOCATION OF LARVAL STAGES IN}

THE DIGESTIVE MUCOSA AND ARRESTED DEVELOPMENT (Tables I, III)

According to Chabaud (1955), the life cycle of primitive Strongylida (Ancylostoma type), begins with cutaneous penetration of exsheathed infective larvae, followed by the migration of larvae via the circulatory or lymphatic system to the lungs. The larvae are subsequently coughed up and swallowed, thus arriving at their definitive site, the intestine. The Trichostrongylina, which are parasites of hosts whose diet is herbivorous, such as lagomorphs, ruminants and arvicolin rodents, have a completely different life cycle with penetration of sheathed infective larvae by the oral route and the absence of pulmonary migration. However, the intra-tissular maturation present in the larval stages of the primitive life cycles, is replaced in these parasites, by penetration of the larvae into the gastric or intestinal mucosa. This penetration is either superficial or deep, depending on the genus of the parasite. (Table I). This phenomenon highlights the fact that an intra-tissular phase is essential to larval development.

This mucosal maturation seems to have given rise to acute adaptation in some life cycles because larvae in the mucosa can temporarily arrest their development. This may be interpreted as an adaptative phenomenon in order to limit the number of parasites present (massive or repetitive infestations) or to preserve the parasite when conditions are unfavourable in the natural environment, i.e. seasonal influences on infective larvae on pasture (Levine, 1963; Eysker, 1997; O'Connor et al., 2006) or the host immune responses can inhibit the normal development of the parasitic phase of the life cycle (Eysker, 1978, Christensen et al., 1992).

In the Heligmosomidae, this arrest of development does not exist since the larvae leave the pseudocyst which disappears at the beginning of the patent period. In this case the pseudocysts may represent the final stage needed for larval maturation (N'Zobadila et al., 1996b). 


\section{MORPHOGENESIS}

In the current classification mainly based on the morphology of the adults, the Trichostrongylina parasites of lagomorphs are present in all three super-families (Durette-Desset, 1985). In each super-family, the parasites of lagomorphs are present in the same sub-family (or genus for Trichostrongylus) as those of ruminants (Trichostrongyloidea, Molineoidea) or in the same family (Heligmosomoidea). Morphogenesis pertaining to the ontogenesis of three morphological characters strongly confirmed this classification.

- Intestinal cell number of the free living stage The differences observed between the three superfamilies appear to be correlated to two different larval strategies. In the Trichostrongyloidea and the Heligmosomoidea, the eggs hatch early, the free-living stages and nutrition occurring in the external environment. The development takes place within four to six days in the Trichostrongyloidea (16 intestinal cells) and within three to six days in the Heligmosomoidea (20 intestinal cells). In the Molineoidea (Nematodirinae) the strategy is different; the "free" living stages occur in the egg at the expense of the vitelline reserves but with a low risk of predation, which results in a slow development from 10 to 28 days and only eight intestinal cells.

- Shape of the tails of the larvae

A larval feature, the shape of the tails (L1 to L4), is characteristic of two host groups (lagomorphs/ruminants or lagomorphs/arvicolin rodents) in each of the three super-families (Fig. 3).

- Shape of the L3 alae and synlophe of L4

In L3, the shape of lateral alae is different for the three super-families, but similar within one super-family for both host groups. The synlophe of the adult is an essential character defining the three super-families. In L4, this synlophe is already pre-established as in the adult: absent in the Trichostrongyloidea, with bilateral symmetry in the Molineoidea, without bilateral symmetry in the Heligmosomoidea. This represents additional proof of the systematic value of the synlophe.

\section{MOleCUlar PHYLOGENY}

The phylogenetic tree of the parasites corresponds to the classification proposed by Durette-Desset (1985) and Durette-Desset et al. (1999): in each super-family the parasites of lagomorphs/ruminants or lagomorphs/ arvicolin rodents are monophyletic. Elsewhere, it has been demonstrated that each host group is monophyletic (for lagomorphs and rodents see Luckett \& Hartenberger (1993) and Chaline et al. (1999); for ruminants see Hernandez \& Vrba (2005)). The superposition of the two trees indicates that neither the parasites of lagomorphs nor the parasites of ruminants or arvicolin rodents constitute a monophyletic group (Audebert et al., 2005).

\section{CONCLUSION}

$\mathrm{n}$ the studies concerning the phylogeny of the Trichostrongylina (Durette-Desset \& Chabaud, 1977, 1981, Durette-Desset, 1985; Durette-Desset et al., 1999) the following hypothesis has been constantly developped.

The whole of ancestral Trichostrongylina has been expanded in vertebrates such as amphibians, reptiles, ratits, other birds and in "ancient" mammals such as marsupials, Insectivora, Chiroptera and some rodents. Those hosts appeared before or during the Eocene period. While not belonging to the same phyletic line, they shared the same pattern of life cycle with a cutaneous penetration and a pulmonary migration before reaching the definitive location in the host (gastric or intestinal). By contrast, the life cycles of the parasites of lagomorphs are completely different because infestation occurs by the oral route and tissular migration is reduced. In the current fauna, the majority of parasite species of ruminants which, according to the previous hypothesis originate from parasites of lagomorphs, presents this same type of life cycle (Durette-Desset et al., 1999, Hoberg et al., 2005).

The transition between the two types of life cycle has been brought to the fore in the genus Paralibyostrongylus, Ortlepp, 1939. From the previous hypothesis, this genus is particularly interesting because it parasitises both "ancient" vertebrates and lagomorphs. The life cycle of Paralibyostrongylus hebrenicutus (Lane, 1923), a parasite of Atherurus, was described by Cassone et al. (1992) in this natural model, and also in the guinea pig and the rabbit. However, Paralibyostrongylus spp. is also present, in wild Leporidae. In the classification of Durette-Desset et al., 1999, the genus was situated at the base of the Cooperidae (LibyostrongylinaeCooperiinae). Cassone et al., 1992, showed that there are two transmission routes, which may have made possible the transition from the primitive cycle by cutaneous penetration to the more specialized cycle by the oral route, the latter being responsible for the evolutionary success of the group in large herbivores.

The lagomorphs appear to have a relay role regardless of the parasitic group. The lagomorphs appeared at the upper Eocene period in the Nearctic zone. They were present in Europe and in Asia at the lower Oligocene period and reached Africa in the lower Miocene period.

The contamination of ruminants and arvicolin rodents by the Trichostrongyloidea apparently took place after 
that of the lagomorphs. Later, the switch occurred from many species (Durette-Desset, 1985; DuretteDesset et al., 1999).

Trichostrongyloidea: in the Trichostrongylidae within the genus Trichostrongylus itself, in the Haemonchidae, from Graphidium and Hyostrongylus, in the Cooperiidae, from Paralibyostrongylus and Obeliscoides (Durette-Desset et al., 1999).

Molineoidea: in the Nematodirinae from a common ancestor to Rauschia (Durette-Desset, 1979) and Nematodirus (Rossi, 1983; Hoberg et al., 2005).

Heligmosomoidea: in the Heligmosomidae, from Obbayashinema (Durette-Desset et al., 2000).

The aim of this study was to determine if morphogenesis, biological and molecular data were opposed to the previous hypotheses, based only on morphological data of the parasites and on paleobiogeographical data of the hosts. All the summarized data (chronology of life cycle, adaptation to the experimental host, tissular migration, morphogenesis; molecular phylogeny) are in agreement with the previous hypothesis. These data confirm that the lagomorphs may be considered as "relay" hosts in the evolution of the Trichostrongylina.

\section{ACKNOWLEDGEMENTS}

Si-ming pecial thank are due to Pr A.G. Chabaud and C. Vaucher, Museum of Genova (Switzerland) for their valuable comments on the manuscript, and Dr S. Sen, Museum of Paris (France) for his help about hosts data. We also wish to thank Dr K. Liittschwager (USA) for correcting the English manuscript.

\section{REFERENCES}

Ahluwalia J.S. \& Charleston W.A. Studies on the development of the free-living stages of Cooperia curticei. New Zealand Veterinary Journal, 1974, 22, 191-195.

AlicATA J.E. Life history of the rabbit stomach worm Obeliscoides cuniculi. Journal of Agricultural Research, 1932, 44, 401-420.

Alicata J.E. Observations on the development of Cooperia punctata of cattle in rabbits. The Journal of Parasitology, $1958,44,57$

Anderson N., Armour J., Jennings F.Z., Ritchie J.D. \& Urquhart G.M. Inhibited development of Ostertagia ostertagi. Veterinary Research, 1965, 77, 146-147.

ANDREWS J.S. The life history of the nematode Cooperia curtice $i$ and development of resistance in the sheep. Journal of Agricultural Research, 1939, 58, 771-785.

ARMour J. Bovine ostertagiasis: a review. The Veterinary Record, 1970, 86, 184-190.

Armour J., Bairden K., Holmes P.H., Parkins J.J., Ploeger H., Salman S.K. \& McWilliams P.N. Pathophysiological and parasitological studies on Cooperia oncophora infections in calves. Research Veterinary Science, 1987, 42, 373-381.

ARMour J., JARRETT W.F.H. \& Jennings F.W. Experimental Ostertagia circumcincta infections in sheep: Development and pathogenesis of the single infection. American Journal of Veterinary Research, 1966, 27, 1267-1278.

AudEBERT F. Les Lagomorphes hôtes "relais" dans l'évolution des Nématodes Trichostrongylina. Thèse de Doctorat, Université Paris XII, 1999, 270 p.

Audebert F., Cassone J., Baccam D., Kerboeuf D. \& DuretteDesset M.C. The life cycle of Obbayashinema erbaevae (Nematoda, Heligmosomoidea, Heligmosomidae) in Ochotona rufescens rufescens (Ochotonidae) Parasite, 2001, 8, 325-333.

Audebert F., Cassone J., Hoste H. \& Durette-Desset M.C. Morphogenesis and distribution of Trichostrongylus retortaeformis in the intestine of the rabbit. Journal of Helminthology, 2000, 74, 95-107.

Audebert F., Cassone J., Kerboeuf D \& Durette-Desset M.C. The life cycle of Nematodiroides zembrae (Nematoda, Trichostrongylina) in the rabbit. Journal of Parasitology, 2002b, 88 (5), 898-904.

Audebert F., Cassone J., Kerboeuf D \& Durette-Desset M.C. Development of Trichostrongylus colubriformis and Trichostrongylus vitrinus, parasites of ruminants in the rabbit and comparison with $T$. retortaeformis, Parasitology Research, 2003b, 90, 57-63.

Audebert F., Cassone J., Kerboeuf D \& Durette-Desset M.C. Development of Nematodirus spathiger (Nematoda, Molineoidea), in the rabbit and comparison with others Nematodirus spp. parasites of ruminants. Parasitology Research, 2004, 94, 112-117.

Audebert F., Chilton N., Justine J.L., Gallut C., Tillier A. \& Durette-Desset M.C. Additional molecular evidence to support a sister taxon relationship between heligmosomid and molineid nematodes (Trichostrongylina). Parasitology Research, 2005, 96, 343-346.

Audebert F., Hoste H \& Durette-Desset M.C. Life cycle of Trichostrongylus retortaeformis (Nematoda, Trichostrongyloidea) in its natural host, the rabbit (Oryctolagus cuniculus). Journal of Helminthology, 2002a, 76, 189-192.

Audebert F., Vuong P.N \& Durette-Desset M.C. Intestinal migrations of Trichostrongylus retortaeformis, (Trichostrongylina, Trichostrongylidae) in the rabbit. Veterinary Research, 2003a, 112, 131-146.

BAILEY W.S. Studies on calves experimentally infected with Cooperia punctata (Linstow, 1907) Ransom, 1907. American Journal of Veterinary Research, 1949, 119-129.

BARKER I.K. Intestinal pathology associated with Trichostrongylus colubriformis infection in sheep: histology. Parasitology, 1975, 70, 165-171.

BARKER I.K. \& Beveridge I. Development of villus atrophy in the small intestine of sheep infected with Trichostrongylus rugatus. Veterinary Parasitology, 1983, 13, 67-75.

BARKER I.K. \& FORD G.E. Development and distribution of atrophic enteritis in the small intestine of rabbits infected with Trichostrongylus retortaeformis. Journal of Comparative Pathology, 1975, 85, 427-435. 
Besch E.D. The effect of time and temperature on the infectivity of third-stage larvae of Cooperia punctata (Trichostrongylidae) in the domestic rabbit, Oryctolagus cuniculus L. American Journal of Veterinary Research, 1964, 25, 535-537.

Besch E.D. Biology of Cooperia punctata (Nematoda: Trichostrongylidae) in the domestic rabbit. The Journal of Parasitology, 1965, 51, 139-144.

BeVERIDGE I. \& BARKER I.K. Morphogenesis of Trichostrongylus rugatus and distribution during development in sheep. Veterinary Parasitology, 1983, 13, 55-65.

Beveridge I., Martin R.R. \& Pullman A.L. Development of the parasitic stages of Nematodirus abnormalis in experimentally infected sheep and associated pathology. Proceedings of the Helminthological Society of Washington, 1985, 52, 119-131.

Bizzell W.E. \& Ciordia H. The course of uncomplicated experimental infections with Trichostrongylus colubriformis in calves. The Journal of Parasitology, 1965, 51, 174.

Boisvenue R.J. \& Novilla M.N. Inoculation of conventionally and specific-pathogen-free reared rabbits with Ostertagia ostertagi isolated from cattle. American Journal of Veterinary Research, 1992, 53, 1054-1058.

BOULENGER C.L. The life history of Nematodirus filicollis Rud., a nematode parasite of the sheep's intestine. Parasitology, $1915,8,133-155$.

Bremner K.C. The parasitic life cycle of Haemonchus placei (Place) Ransom (Nematoda: Trichostrongylidae). Australian Journal of Zoology, 1956, 4, 146-151.

CABARET J. Egg output of Graphidium strigosum (Nematoda) in low-level prime infection of rabbits. Folia Parasitologica (Praha), 1981, 28, 337-341.

Cable J., Harris P.D., Lewis J.W. \& BehnKe J.M. Molecular evidence that Heligmosomoides polygyrus from laboratory mice and wood mice are separate species. Parasitology, 2006, 133, 111-122.

Cassone J., Vuong P.N. \& Durette-Desset M.C. Cycle biologique de Paralibyostrongylus bebrenicutus (Nematoda : Trichostrongylidae). Annales de Parasitologie Humaine et Comparée, 1992, 67, 33-41.

Chabaud A.-G. Essai d'interprétation phylétique des cycles évolutifs chez les Nématodes parasites de Vertébrés. Conclusions taxonomiques. Annales de Parasitologie, 1955, 30, 83-126.

Chabaud A.G. Ordre des Strongylida, in : Grassé P.P. (ed.). Traité de zoologie, Némathelminthes (Nématodes-Gordiacés) Rotifères, Gastrotriches Kinorhynques. Spécificité parasitaire chez les Nématodes parasites de Vertébrés, 1965, Tome IV, fascicule III, 548-557.

Chaline J., Brunet-Lecomte P., Montuire S., Viriot L. \& CouRANT F. Anatomy of the arvicoline radiation (Rodentia): palaeogeographical, palaeoecological history and evolutionary data. Annales Zoologici Fennici, 1999, 36, 239-267.

Christensen C.M., Nansen P., Henriksen S.A., Monrad J. \& SATRIJA F. Attempts to immunize cattle against Ostertagia ostertagi infections employing normal and chilled (hypobiosis-prone) third stage larvae. Veterinary Parasitology, 1992, 44, 247-261.
Ciordia H. \& Bizzell W.E. The effects of various constant temperatures on the development of the free-living stages of some nematode parasites of cattle. The Journal of Parasitology, 1963, 49, 60-63.

Ciordia H., Bizzell W.E., Porter D.A. \& Dixon C.F. The effect of culture temperature and age on the infectivity of the larvae of Trichostrongylus axei and T. colubriformis in rabbits and guinea pig. The Journal of Parasitology, 1966, 52, 866-870.

Denham D.A. The development of Ostertagia circumcincta in lambs. Journal of Helminthology, 1969, 43, 299-310.

Dikmans G. \& ANDREws J.S. A comparative morphological study of the infective larvae of the common nematodes parasitic in the alimentary tract of sheep. Transactions of the American Microscopical Society, 1933, 52, 1-25.

Dineen J.K., Donald A.D., Wagland B.M. \& Turner J.H. The dynamics of the host-parasite relationship. II. The response of sheep to primary and secondary infection with Nematodirus spathiger. Parasitology, 1965, 55, 163-171.

DOUVRES F.W. Morphogenesis of the parasitic stages of Ostertagia ostertagi, a nematode parasite in cattle. The Journal of Parasitology, 1956, 42, 626-635.

Douvres F.W. The morphogenesis of the parasitic stages of Trichostrongylus axei and Trichostrongylus colubriformis, nematode parasites of cattle. Proceedings of the Helminthological Society of Washington, 1957, 24, 4-14.

Drudge J.H., Leland S.E., Wyant Z.N. \& Elam G.W. Studies on Trichostrongylus axei (Cobbold, 1879) I. Some experimental host relationships. The Journal of Parasitology, 1955, 41, 505-511.

Durette-Desset M.C Les Nematodirinae (Nematoda) chez les Ruminants et chez les Lagomorphes. Annales de Parasitologie Humaine et Comparée, 1979, 54, 313-329.

Durette-Desset M.C. Trichostrongyloid nematodes and their vertebrate hosts: reconstruction of the phylogeny of a parasitic group. Advances in Parasitology, 1985, 24, 239-306.

Durette-Desset M.C. \& Chabaud A.G. Essai de classification des Nématodes Trichostrongyloidea. Annales de Parasitologie Humaine et Comparée, 1977, 52, 539-558.

Durette-Desset M.C. \& Chabaud A.G. Nouvel essai de classification des Nématodes Trichostrongyloidea. Annales de Parasitologie Humaine et Comparée, 1981, 56, 297-312.

Durette-Desset M.C. \& Chabaud A.G. Nomenclature des Strongylida au-dessus du groupe-famille. Annales de Parasitologie Humaine et Comparée, 1993, 68, 111-112.

Durette-Desset M.C., Hugot J.P., Darlu P. \& Chabaud A.G. A cladistic analysis of the Trichostrongyloidea (Nematoda). International Journal for Parasitology, 1999, 29, 1065-1086.

EYSKER M. Inhibition of the development of Trichostrongylus spp. as third stage larvae in sheep. Veterinary Parasitology, 1978, 4, 29-33.

EYSKER M. Some aspect of inhibited development of trichostrongylids in ruminants. Veterinary Parasitology, 1997, 72, 265-283.

FORD G.E. The relationship between a nematode parasite Trichostrongylus retortaeformis and its host or environment. Thesis submitted to the Australian National University for the degree of Doctor of Philosophy, 1971, 250 p. 
Gallie G.J. Development of the parasitic stages of Nematodirus battus in the laboratory rabbit. Parasitology, 1972, 64, 293-304.

GibBs H.C. Hypobiosis in parasitic nematodes - An update, Advances in Parasitology, 1986, 25, 129-174.

Haupt W. Untersuchungen zum Verlauf des Befalls mit Trichostrongylus retortaeformis (Zeder, 1800) Looss, 1905, beim Hauskaninchen (Oryctolagus cuniculus). (In German) Archives Experimental Veterinary Medicine, 1973, 135141.

HAupT W. \& Nickel E.A. Course of the parasite phase of development of Trichostrongylus axei (Cobbold, 1879) Raillet et Henry, 1909, in domestic rabbit. (In German) Archives Experimental Veterinary Medicine, 1975, 29, 129-134.

Herlich H. The life history of Nematodirus helvetianus May, 1920, a nematode parasitic in cattle. The Journal of Parasitology, 1954, 40, 60-70.

Herlich H. The development of Cooperia pectinata, a nematode parasite of cattle. American Journal of Veterinary Research, 1965a, 26, 1026-31.

Herlich H. The effects of the intestinal worms, Cooperia pectinata and Cooperia oncophora, on experimentally infected calves. American Journal of Veterinary Research, 1965b, 26, 1032-1036.

Herlich H., Porter D.A. \& Knight R.A. A study of Haemonchus in cattle and sheep. American Journal of Veterinary Research, 1958, 19, 866-872.

Hernandez Fernandez M. \& VRBa E.S. A complete estimate of the phylogenetic relationships in Ruminantia: a dated species-level super tree of the extant ruminants. Biological review of the Cambridge Philosophical Society, 2005, 80, 269-302.

Hoberg E.P., Lichtenfels J.R. \& Rickard L.G. Phylogeny for genera of Nematodirinae (Nematoda: Trichostrongylina). The Journal of Parasitology, 2005, 91, 382-389.

Hung S.L. The pathology of Cooperia punctata infestation in calves. The North American Veterinarian, 1926, 33-36.

Hutchinson G.W. \& SLOcombe J.O.D. Experimentally induced Haemonchus contortus infections in the rabbit. Journal of Helminthology, 1976, 50, 143-152.

IsENSTEIN R.S. The life history of Cooperia oncophora (Railliet, 1898) Ransom, 1907, a nematode parasite of cattle. The Journal of Parasitology, 1963, 49, 235-240.

KATES K.C. \& TURNer J.H Observations on the life cycle of Nematodirus spathiger, a nematode parasitic in the intestine of sheep and others ruminants. American Journal of Veterinary Research, 1955, 16, 105-115.

KeITH R.K. The differentiation of the infective larvae of some common nematode parasites of cattle. Australian Journal of Zoology, 1952, 1, 223-235.

LELAND S.E. \& DRudge J.H. Studies on Trichostrongylus axei (Cobbold, 1879). II. Some quantitative aspect of experimental infections in rabbits. The Journal of Parasitology, 1957, 43, 160-166.

LEVINE N.D. Weather, climate, and the bionomics of ruminant nematode larvae, in: Brandly C.A. \&. Jungherr E.L (eds). Advances in Veterinary Science, Academic Press Inc., London, New York, 1963, 215-261.
LUCKeTT W.P. \& HARTENBERGER J.L. Monophyly or polyphyly of the order Rodentia: possible conflict between morphological and molecular interpretations. Journal of Mammalian Evolution, 1993, 1, 127-147.

Mac KenNa M.C. \& BeLl S.K. Classification of mammals above the species level. Columbia University Press, New York, 1997, $631 \mathrm{p}$.

Mapes C.J. \& CoOp R.L. The development of single infections of Nematodirus battus in lambs. Parasitology, 1972, 64, 197-216.

Mapes C.J. \& Gallie G.J. The development of Haemonchus contortus, a nematode parasite of the ovine abomasum, in the laboratory rabbit. Parasitology, 1977, 74, 235-242.

MEASURES L.N. \& ANDERSON R.C. Characteristics of natural infections of the stomach worm, Obeliscoides cuniculi (Graybill), in lagomorphs and woodchucks in Canada. Journal of Wildlife Diseases, 1983, 19, 219-224.

Michel J.F. Self-cure in infections of Trichostrongylus retortaeformis and its causation. Nature, 1952a, 169, 881.

Michel J.F. Inhibition of development of Trichostrongylus retortaeformis. Nature, 1952b, 169, 933-934.

Michel J.F. Arrested development of nematodes and some related phenomena. Advances in Parasitology, 1974, 12, 279-366.

Michel J.F., LANCASTER M.B. \& Hong C. Observations on the inhibition of development of Cooperia oncophora in calves. The British Veterinary Journal, 1970, 126, 35-37.

MÖNNIG H.O. The life histories of Trichostrongylus intestinalis and T. rugatus of sheep in South Africa. 11-12 ${ }^{\text {th }}$ Annual Report of the Director of Veterinary Education and Research, Union of South Africa, 1927, 231-251.

N'Zobadila G. Biologie d'Heligmosomoides polygyrus polygyrus (Dujardin, 1845) (Nematoda-Trichostrongylina). Comparaison avec les espèces proches et sa sous-spéciation américaine. Thèse de Doctorat, Muséum National d'Histoire Naturelle, Paris, 1994, 183 p.

N'Zobadila G., Boyer J. \& Durette-Desset M.C. Morphogenèse d'Heligmosomoides polygyrus polygyrus (Dujardin, 1845) (Trichostrongylina, Heligmosomoidea) chez Apodemus flavicollis en France. Comparaison avec les espèces proches : Heligmosomoides laevis (Dujardin, 1845) et Heligmosomum mixtum Schulz, 1954, parasites d'Arvicolidae. Bulletin du Muséum National d'Histoire Naturelle, Paris, 4è série, 1996a, 18, 367-385.

N'Zobadila G., Boyer J., Vuong P.N. \& Durette-Desset M.C. Chronologie du cycle et étude des pseudo-kystes d'Heligmosomoides polygyrus polygyrus (Dujardin, 1845) (Trichostrongylina-Heligmosomoidea) chez Apodemus flavicollis en France. Comparaison avec les espèces proches. Parasite, 1996b, 3, 237-246.

O'CONNOR L.J., WaLKden-Brown S.W. \& KaHn L.P. Ecology of the free-living stages of major trichostrongylid parasites of sheep. Veterinary Parasitology, 2006, 142, 1-15.

OGunsusi R.A. \& EYsKer M. Inhibited development of trichostrongylids of sheep in northern Nigeria. Research in Veterinary Science, 1979, 26, 108-110.

ONAR E. Observations on Nematodirus abnormalis (May 1920): isolation, eggs and larvae, pre-parasitic development. The British Veterinary Journal, 1975, 131, 231-239. 
Purvis G.M. \& SEwell M.M.H. The host-parasite relationship between the domestic rabbit and Trichostrongylus colubriformis. BVA Annual congress, Lancaster University, September $5^{\text {th }}$ to $10^{\text {th }}$. The Veterinary Record, 1971, 151-152.

Purvis G.M. \& Sewell M.M.H. Trichostrongylus colubriformis: age resistance in the rabbit, Oryctolagus cuniculus. Experimental Parasitology, 1972, 32, 191-195.

RaHMAn W.A. \& Collins G.H. The establishment and development of Trichostrongylus colubriformis in goats. Veterinary Parasitology, 1990, 35, 195-200.

RANSOM B.H., Intestinal lesions in calves due to Cooperia punctata. The Journal of Parasitology, 1920, 96-97.

Rose J.H. The development of the parasitic stages of Ostertagia ostertagi. Journal of Helminthology, 1969, 43, 173-184.

Ross J.G., Purcell D.A., Dow C. \& Tood J.R. Experimental infections of calves with Trichostrongylus axei; the course and development of infection and lesions in low level infections. Research in Veterinary Science, 1967, 8, 201206.

Rose J.H \& Small A.J. Observations on the bionomics of the free-living stages of Trichostrongylus vitrinus. Journal of Helminthology, 1984, 58, 49-58.

Rossi P. Sur le genre Nematodirus Ransom, 1907 (Nematoda : Trichostrongyloidea). Annales de Parasitologie Humaine et Comparée, 1983, 58, 557-581.

Silverman P.H. \& Patterson J.E. Histotropic (parasitic) stages of Haemonchus contortus. Nature, 1960, 185, 54-55.

Snider T.G., Williams J.C., Romaire T.L. \& Besh E.D. Experimentally induced ostertagiosis in rabbits inoculated with Ostertagia ostertagi of bovine origin. American Journal of Veterinary Research, 1985, 46, 2184-2187.

SOllod A.E., HaYes T.J. \& SoulsBy E.J.L. Parasitic development of Obeliscoides cuniculi in rabbits. The Journal of Parasitology, 1968, 54, 129-132.

SOMMERVILLE R.I. Development of Ostertagia circumcincta in the abomasal mucosa of the sheep. Nature, 1953a, 171, 482-483.

SOMmERVILLE R.I. The histotrophic phase of the nematode parasite, Ostertagia circumcincta. Australian Journal of Agricultural Research, 1953b, 5, 130-144.

Sommervilue R.I. The growth of Cooperia curticei (Giles, 1892), a nematode parasite of sheep. Parasitology, 1960, 50, 261267.

STEWART T.B. The life history of Cooperia punctata, a nematode parasitic in cattle. Journal of Parasitology, 1954, 40, 321-327.

TAylor S.M. \& Pearson G.R. Trichostrongylus vitrinus in sheep. I: The location of nematodes during parasitic development and associated pathological changes in the small intestine. Journal of Comparative Pathology, 1979, 89, 397-403

Thomas R.J. A comparative study of the infective larvae of Nematodirus species parasitic in sheep. Parasitology, 1957, 47, 60-65.

Thomas R.J. A comparative study of the life histories of Nematodirus battus and $N$. filicollis, nematode parasites of sheep. Parasitology, 1959, 48, 374-386.
Threlkeld W.L. The life history of Ostertagia circumcincta. Technical bulletin $\mathrm{n}^{\circ} 5$, Virginia Polytechnic Institute, Virginia Agricultural Experimental Station, Blacksburg, Virginia, USA, 1934, 5, $24 \mathrm{p}$.

Threlkeld W.L. The life history of Ostertagia ostertagi. Technical bulletin $\mathrm{n}^{\circ} 100$, Virginia Polytechnic Institute, Virginia Agricultural Experimental Station, Blacksburg, Virginia, USA, 1946, 100, 14 pp.

Veglia F. The anatomy and life-history of the Haemonchus contortus (Rud). The $3^{\text {rd }}$ and $4^{\text {th }}$ reports of the Director of Veterinary Research Laboratories, Union of South Africa, Pretoria, 1916, 349-500.

Watkins A.R.J. \& Fernando M.A. Arrested development of the rabbit stomach worm Obeliscoides cuniculi: manipulation of the ability to arrest through processes of selection. International Journal for Parasitology, 1984, 14, 559-570.

WatKInS A.R.J. \& FERNANDO M.A. Arrested development of the rabbit stomach worm Obeliscoides cuniculi: varied responses to cold treatment by offspring produced throughout the course of the single infection. International Journal for Parasitology, 1986, 16, 55-61.

Wetzel R. \& ENigK K. Zur Biologie von Graphidium strigosum, dem Magenwurm der Hasen und Kaninchen. Deutsche Tierärztliche Wochenschrift, 1937, 25, 401-405.

WOOD I.B \& HANSEN M.F. Experimental transmission of ruminant nematodes of the genera Cooperia, Ostertagia, and Haemonchus to laboratory rabbits. The Journal of Parasitology, 1960, 46, 775-776.

Zebrowska-Plata D. Attempts to attain development of the sheep nematode Ostertagia circumcincta (Stadelman, 1894) in unusual hosts: rabbits and guinea pigs. Acta Parasitologica Polinica, 1980, 27, 213-220.

Reçu le 30 décembre 2006 Accepté le 22 mars 2007 
